\title{
Oral health knowledge and behavior among male health sciences college students in Kuwait Jassem Al-Ansari*1, Eino Honkala ${ }^{2}$ and Sisko Honkala ${ }^{2}$
}

\author{
Address: ${ }^{1}$ Department of Oral \& Dental Health, College of Health Sciences, The Public Authority for Applied Education and Training, Kuwait and \\ ${ }^{2}$ Department of Developmental and Preventive Sciences, Faculty of Dentistry, Kuwait University, Kuwait \\ Email: Jassem Al-Ansari* - jansari@paaet.edu.kw; Eino Honkala - Eino.Honkala@hsc.kuniv.edu.kw; \\ Sisko Honkala - Sisko.Honkala@hsc.kuniv.edu.kw \\ * Corresponding author
}

Published: 7 May 2003

BMC Oral Health 2003, 3:2

This article is available from: http://www.biomedcentral.com/I472-683I/3/2

(C) 2003 Al-Ansari et al; licensee BioMed Central Ltd. This is an Open Access article: verbatim copying and redistribution of this article are permitted in all media for any purpose, provided this notice is preserved along with the article's original URL.

\begin{abstract}
Background: Health auxiliary personnel have an important role in oral health promotion when they graduate and start working in the health care system. This study aims to find out oral health knowledge and oral health behavior of male Health Sciences College students.

Methods: A questionnaire was distributed to all students at the male Health Sciences College in Kuwait $(N=153)$ during the academic year 200I/2002. The students filled the anonymous questionnaire in the class after the lecture. The response rate was $84 \%(n=128)$. The questions consisted information on the general background, oral health behavior and oral health knowledge.

Results: Oral health knowledge seemed to be limited and very few background factors were associated with it. More than half of the students had visited a dentist during the previous 12 months, but only one third of students were brushing twice a day or more often.

Conclusions: It may be concluded that the male Health Sciences College students seemed to have appropriate knowledge on some oral health topics, but limited knowledge on the others. Their toothbrushing practices are still far behind the international recommendation (twice a day) and also the knowledge, why it should be done so frequently also very limited.
\end{abstract}

\section{Background}

Oral diseases are clearly related to behavior, and the prevalence of dental caries and periodontal disease has decreased with improvements in oral hygiene and a decrease in the consumption of sugar products. This general favorable trend in reducing dental caries, however, has not been seen in several developing countries [1] or in the Middle East [2,3]. While twice-a-day toothbrushing seems to be an established practice in several industrialized countries such as the United Kingdom [4], Italy [5], Swe- den [6], and Norway [7], this goal is still very far from being realized in several other countries, including Turkey [8], Lebanon [9], Saudi Arabia [2] and Kuwait [10,11].

Oral health knowledge is considered to be an essential prerequisite for health-related behavior [12], although only a weak association seems to exist between knowledge and behavior in cross-sectional studies $[13,14]$. Nevertheless, studies have shown that there is an association between increased knowledge and better oral health $[15,16]$. 
Since auxiliary health personnel specialize in preventive information and health promotion, it is important that their own oral health knowledge is good and their oral health behavior conforms to professional recommendations. With proper knowledge and oral health behavior, they can play an important role in the health education of individuals and groups [17-20], and act as role models for lay people and the community at large.

The aim of this study is to determine oral health knowledge and behavior among students at the male Health Sciences College in Kuwait, which graduates auxiliary health personnel.

\section{Methods}

The Health Sciences College, formerly the Health Institute, was established in 1974, with separate colleges for female and male students. The programs offered are: General Nursing, Pharmaceutical and Medical Sciences, Oral and Dental Health (females only), Medical Records, Environmental Health, Food Sciences and Nutrition, and Medical Laboratory Technology (females only).

A questionnaire was distributed to all students at the male Health Sciences College $(\mathrm{N}=153)$ during the academic year 2001/2002 See additional file: 1 . The students were requested to remain in the classroom after the lecture and to fill in the questionnaire. The participation was voluntary and the answers were anonymous. Altogether 28 returned the questionnaire, giving a response rate of $84 \%$

The questions consisted of:

1) Background: age (18-20 years, $21-25$ years, 26 years and over); marital status (single, married); nationality (Kuwaiti, non-Kuwaiti); years in College (one year, two or more years); financial status (satisfactory, not satisfactory); dental disease (yes, no/don't know); perceived oral health (poor, average, good).

2) Oral health knowledge: role of sugar, bacteria and soft drinks in dental caries; baby teeth brushing after bottle feeding; fluoride toothpaste for baby teeth; occurrence of periodontal diseases in men; transmission of bacteria from the father to his child; plaque; calculus; dental diseases; extraction of teeth, if painful; what is orthodontics; role of fluoride in toothpaste.

3) Oral health behavior: last dental visit (during last year, more than a year ago); purpose of dental visit (examination/prevention, treatment); toothbrushing frequency (less than once a day, once a day, more than once a day); use of fluoride toothpaste (yes, no/don't know); amount of toothpaste on toothbrush (less than half, half, more than half).
Data on behavior and knowledge were analyzed according to age, marital status, nationality, years in college, financial status and perceived oral health. The data were processed by SPSS-PC, version 10. Analysis of variance (ANOVA) were used for evaluation of the statistical significance. All of the knowledge answers (13) were summarized by giving equal weight (1) for each of the correct answers. The mean values were then compared against the background factors and oral health behavior.

\section{Results}

Almost all students know the role of fluorides in caries prevention, the role of sugar in caries etiology, and that extraction is not the only treatment for a painful tooth (Fig. 1). Only few knew what orthodontics means, that a father could transmit Str. Mutans to the child, and what calculus is. One third of the respondents knew about the risk of periodontal disease and that baby teeth need to be brushed after bottle feeding.

When the additive knowledge summary variable was analyzed according to different independent variables, only a few associations were detected (Table 1). Single students seemed to have better knowledge than married ones and Kuwaiti students better than non-Kuwaitis. From the oral health behavior variables, only the use of fluoride toothpaste seemed to be significantly associated with the knowledge.

Most of the students $(60 \%)$ had visited a dentist during the last year, $11 \% 1-2$ years ago and $29 \%$ more than two years ago (Fig. 2). More than half of the students were seeking the dentist for the treatment. Altogether 34\% of the students were brushing twice a day or more often, $45 \%$ once a day and $20 \%$ less than once a day. Most of the students $(70 \%)$ used fluoride toothpaste, $11 \%$ did not use it and $20 \%$ did not know whether they were using it or not. The amount of toothpaste used was less than half of the toothbrush by $11 \%$, about half by $34 \%$ and more than half by $55 \%$.

\section{Discussion}

Although oral health knowledge does not necessarily relate to better health behavior, people who have assimilated this knowledge and feel a sense of personal control over their oral health are more likely to adopt self-care practices [13]. Oral health knowledge was expected to be good among the Health Sciences College students in this study, because it is important content in their professional education, and they need this knowledge to educate patients and the community when they start working in health care system. These students seemed to be well aware about the most important aspects of oral health care, i.e. effects of sugar consumption, effects of fluorides as well as visiting the dentist. However, there seemed to be 


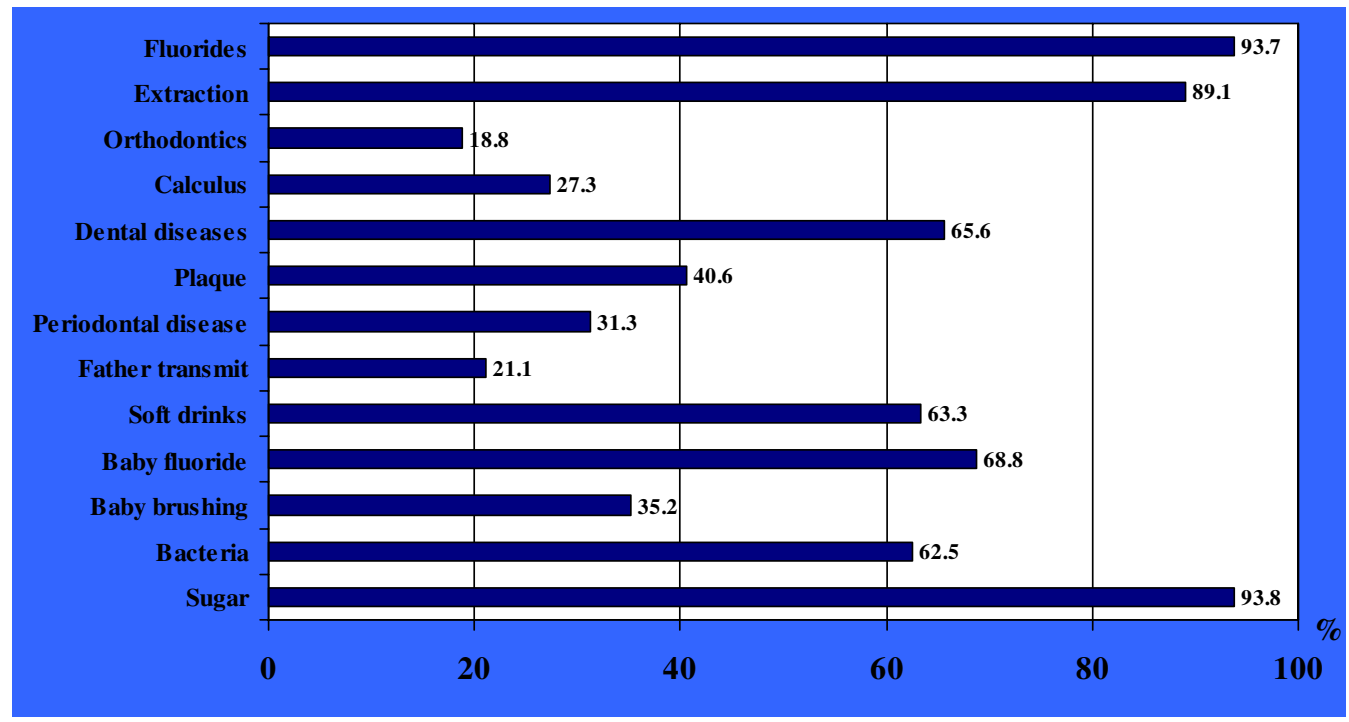

Figure I

The proportion (\%) of the correct answers to the knowledge questions by the college students.

areas i.e. the role of plaque, periodontal diseases, transmission of oral bacteria, where their knowledge was poor. Other studies have also shown that there is in general much work to do in improving dental health knowledge even among dental hygiene students [21], dental students [22], other university students $[23,24]$ and teachers [25$28]$.

There are very few studies with the representative from Kuwait on the knowledge and the behavior. Therefore these results have are discussed in relation to the other studies, one of them being a national oral health survey almost 20 years ago, which has just recently published [11]. These data were destroyed during the Gulf War. Education in general is segregated in Kuwait and thus there is also a college for females, but this study was conducted only in male college. Therefore the gender comparison is not possible.
Oral health knowledge among the HSC students was most strongly associated with the use of fluoride toothpaste. Although $94 \%$ of the respondents knew the role of fluorides, not all of them actually used fluoride toothpaste. Their knowledge of the role of fluorides and sugar in the process of caries formation and various treatment options for a painful tooth was very good, but all the other measured aspects of oral health knowledge were not as high as could have been expected. It was also alarming that there was no significant difference in knowledge between the first year and the more advanced students. One earlier study [21] showed that second year dental hygiene students had more advanced attitudes/behavior than the first year students, which was a logical hypothesis. However, in the present study there seemed to be only a slight increase in knowledge with increasing age in this study. Single persons had better knowledge than married ones. It was expected that married students would have been more 


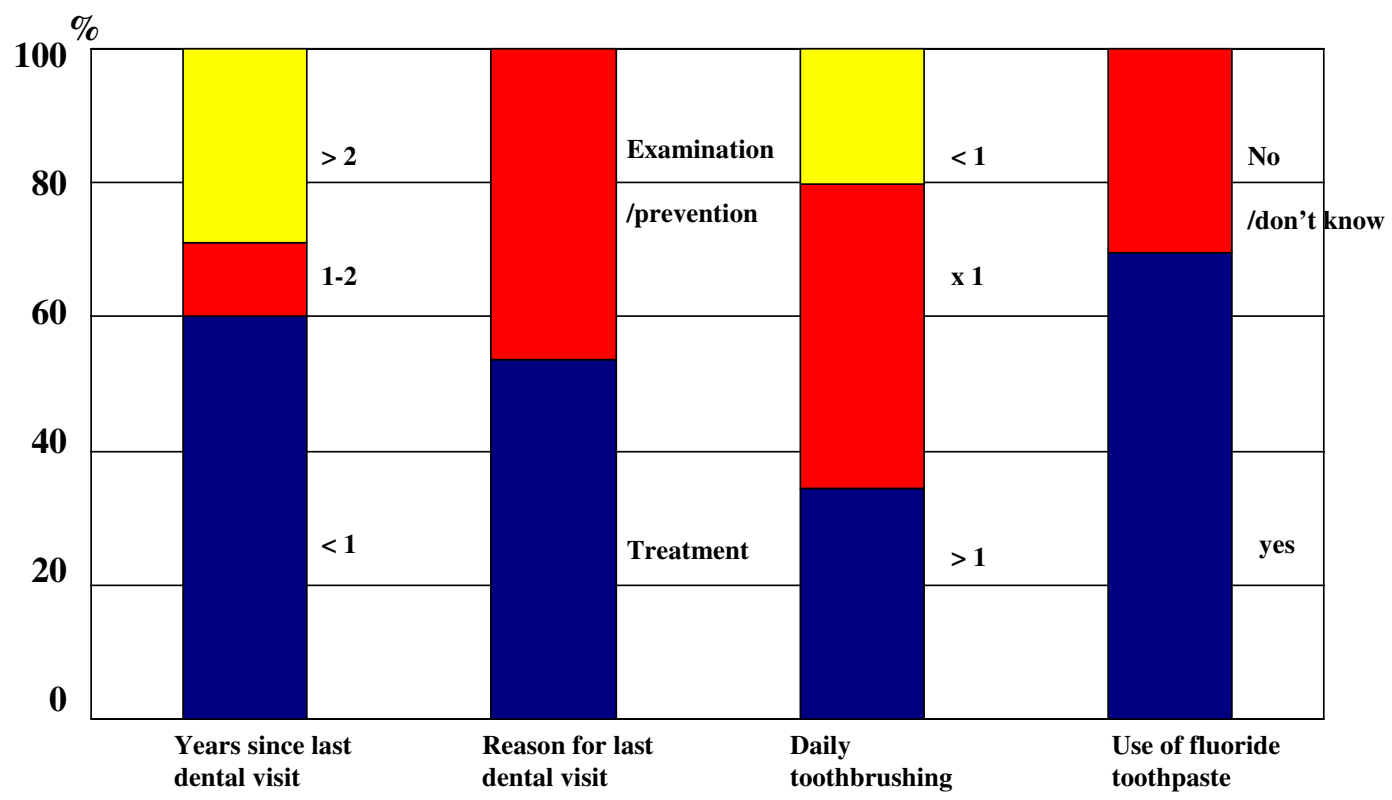

Figure 2

Oral health behavior of college students.

concerned about health issues and therefore would also had more knowledge than the single ones.

More than half (60\%) of the students had visited a dentist during the last 12 months, which is a higher proportion than that found in the survey of the total Kuwaiti population (39\%) [11]. However, toothbrushing frequency of twice a day or more was not common; only one third of the respondents were brushing as generally recommended. Also the proportion of those students who were brushing less than once a day was high $(20 \%)$, corresponding to the respective proportion in the illiterate population (24\%) in the only national oral health survey in 19841985 [11]. A slightly higher proportion of twice-a-day brushers have been reported among 12-year-old Kuwaitis (47\% among boys and 62\% among girls) [10] and Saudi Arabian schoolchildren [2]. In Lebanon, the proportion of twice-a-day brushers among college students was also higher (65\%) [9], but lower (25\%) among 15-18-yearolds in Turkey [8]. Much more health education needs to be done already at schools for establishing appropriate toothbrushing and flossing practice in Kuwait. Dental health education in Kuwait is supposed to be organized by school oral health programs but currently they cannot cover all the schools. This study was conducted also for demonstrating the possible need for improvement in oral health knowledge and the problems in oral health behavior of these young Kuwaiti students especially.

Pea size amount of toothpaste is recommended for toothbrushing, and manufacturers in their advertisements use this amount. However, only $11 \%$ of the students in this study used toothpaste less than half of the length of toothbrush. The larger amount of toothpaste does not improve the effect of the mechanical cleaning or the preventive effect of fluoride. As role models, these college students 
Table I: Summary variable of knowledge concerning dental health by different background factors (ANOVA).

\begin{tabular}{|c|c|c|c|c|}
\hline Variable & $\mathrm{n}$ & Mean & SD & P-value \\
\hline \multicolumn{5}{|l|}{ Age } \\
\hline - 18-20 years & 59 & 7.1 & 2.2 & \\
\hline$-21-25$ years & 54 & 7.6 & 2.1 & \\
\hline - 26 and over & 15 & 8.3 & 2.2 & $0.120 \mathrm{~ns}$ \\
\hline \multicolumn{5}{|l|}{ Marital status } \\
\hline - Single & 107 & 8.3 & 1.9 & \\
\hline - Married & 21 & 7.2 & 2.2 & $0.033 *$ \\
\hline \multicolumn{5}{|l|}{ Nationality } \\
\hline - Kuwaiti & 69 & 7.9 & 2.1 & \\
\hline - Non-Kuwaiti & 59 & 6.9 & 2.1 & $0.012 *$ \\
\hline \multicolumn{5}{|l|}{ Years in College } \\
\hline - One year & 88 & 7.3 & 2.1 & \\
\hline - Two or more & 40 & 7.7 & 2.2 & $0.308 \mathrm{~ns}$ \\
\hline \multicolumn{5}{|l|}{ Financial status } \\
\hline - Very good/good & 116 & 7.4 & 2.2 & \\
\hline - Below average & 15 & 7.4 & 1.6 & 0.989 ns \\
\hline \multicolumn{5}{|c|}{ Do you think that you have dental diseases? } \\
\hline - Yes & 47 & 7.5 & 2.1 & \\
\hline - No/Don't know & 61 & 7.4 & 2.2 & $0.704 \mathrm{~ns}$ \\
\hline \multicolumn{5}{|l|}{ Perceived oral health } \\
\hline - Poor & 19 & 7.3 & 2.0 & \\
\hline - Average & 72 & 7.4 & 2.2 & \\
\hline - Good & 37 & 7.6 & 2.1 & $0.852 \mathrm{~ns}$ \\
\hline \multicolumn{5}{|l|}{ Last dental visit } \\
\hline - During last year & 77 & 7.4 & 2.2 & \\
\hline - More than year ago & 51 & 7.5 & 2.1 & $0.912 \mathrm{~ns}$ \\
\hline \multicolumn{5}{|l|}{ Purpose of visit } \\
\hline - Examination/prevention & 53 & 7.3 & 2.0 & \\
\hline - Treatment & 61 & 7.6 & 2.3 & $0.474 \mathrm{~ns}$ \\
\hline \multicolumn{5}{|l|}{ Toothbrushing frequency } \\
\hline - Less than once a day & 27 & 7.4 & 1.0 & \\
\hline - Once a day & 53 & 7.4 & 2.2 & \\
\hline - More than once a day & 41 & 6.9 & 2.4 & $0.187 \mathrm{~ns}$ \\
\hline \multicolumn{5}{|l|}{ Use of fluoride toothpaste } \\
\hline - Yes & 81 & 7.8 & 2.2 & \\
\hline - No/don't know & 40 & 6.6 & 1.9 & $0.002 * *$ \\
\hline
\end{tabular}

** $\mathrm{p}<0.01 ; * \mathrm{p}<0.05 ; \mathrm{ns} \mathrm{p} \geq 0.05$

should follow professional recommendations in their own behavior.

It may be concluded that the male Health Sciences College students seemed to have appropriate knowledge on some oral health topics, but limited knowledge on the others. Their toothbrushing practices are still far behind the international recommendation (twice a day) and also the knowledge, why it should be done so frequently also very limited.

\section{Additional material}

\section{Additional file 1}

Oval heath survey 2002

Click here for file

[http://www.biomedcentral.com/content/supplementary/14726831-3-2-S1.doc]

\section{References}

I. Sheiham A Changing trends in dental caries Int J Epidemiol 1984, I3:| $142-147$

2. Al-Tamini S and Petersen PE Oral health situation of schoolchildren, mothers and schoolteachers in Saudi Arabia Int Dent J 1998, 48: $180-186$ 
3. Al-Mutawa S, Al-Duwairi Y, Honkala E, Honkala S and Shyama M The trends of dental caries experience of children in Kuwait Dent News 2002, 9:9-13

4. Bradnock G, White DA, Nuttall NM, Morris AJ, Treasure ET and Pine CM Dental attitudes and behaviours in 1998 and implications for the future $B$ r Dent J 200I, I 90:228-232

5. Rimondini L, Zolfanelli B, Bernardi F and Bez C Self-preventive oral behavior in an Italian university student population J Clin Periodontol 200I, 28:207-2II

6. Stenberg $\mathrm{P}$, Håkansson $\mathrm{J}$ and Åkerman S Attitudes to dental health and care among 20 to 25 -year-old Swedes: results from a questionnaire Acta Odontol Scand 2000, 58:102-106

7. Åstrøm AN and Samdal O Time trends in oral health behaviors among Norwegian adolescents Acta Odontol Scand 2001, 59:193200

8. Kulak-Özkan Y, Ozkan Y, Kazazoglu E and Arikan A Dental caries prevalence, tooth brushing and periodontal status in 150 young people in Istanbul: A pilot study Int Dent J 200 I, 5 I:45 I456

9. Kassak KM, Dagher R and Doughan B Oral hygiene and lifestyle correlates among new undergraduate University students in Lebanon J Am Coll Health 200I, 50:I5-20

10. Vigild M, Petersen PE and Hadi R Oral health behaviour of I2year-old children in Kuwait Int J Paediatr Dent 1999, 9:23-29

II. Behbehani JM and Shah NM Oral health in Kuwait before the Gulf war Med Principles Pract 2002, I I:36-43

12. Ashley FP Role of dental health education in preventive dentistry In: Prevention of dental disease (Edited by: Murray JJ) Oxford: Oxford University Press 1996, 406-4I4

13. Freeman R, Maizels J, Wyllie M and Sheiham A The relationship between health related knowledge, attitudes and dental health behaviours in 14-16-year-old adolescents Community Dent Health 1993, 10:397-404

14. Kay EJ and Locker D A systematic review of the effectiveness of health promotion aimed at improving oral health Community Dent Oral Epidemiol 1998, 26:132-|44

15. Woodgroove J, Cumberbatch $\mathrm{G}$ and Gylbier S Understanding dental attendance behavior Community Dent Health 1987, 4:2 I5-22 I

16. Hamilton ME and Coulby WM Oral health knowledge and habits of senior elementary school students J Publ Health Dent 1991, 5 I:2। $2-218$

17. Uitenbrock DG, Schauls RMM, Tromp JAH and Kaut JH Dental hygienists' influence on the patients' knowledge, motivation, self-care, and perception of change Community Dent Oral Epidemiol 1989, 17:87-90

18. Abraham NJ, Cirincione UK and Glass RT Dentists' and dental hygienists' attitudes toward toothbrush replacement and maintenance Clin Prev Dent 1990, I 2:28-33

19. McGonaughy FL, Lucken KM and Toevs SE Health promotion behaviors of private practice dental hygienists J Dent Hyg 1991, 65:222-230

20. Brown LF A comparison of patients attending general dental practices employing or not employing dental hygienists Aust Dent J 1996, 41:47-52

21. Kim K-J, Komabayashi T, Moon S-E, Goo K-M, Okada M and Kawamura $M$ Oral health attitudes/behavior and gingival self-care level of Korean dental hygiene students J Oral Sci 2002, 43:49-53

22. Kawamura M, Honkala E, Widtröm E and Komabayashi T Cross-cultural differences of self-reported oral health behaviour in Japanese and Finnish dental students Int Dent J 2000, 50:46-50

23. Murtomaa $H$, Turtola $L$ and Rytömaa I Dental health practices among Finnish university students Proc Fin Dent Soc 1989, 80:155-161

24. Åstrøm AN and Masalu JR Oral health behavior patterns among Tanzanian university students: a repeat cross-sectional survey BMC Oral Health 200 I, I:I-I2

25. Petersen PE, Danila I and Samoila A Oral health behavior, knowledge, and attitudes of children, mothers and schoolteachers in Romania in 1993 Acta Odontol Scand 1995, 53:363-368

26. Lang $P$, Woolfolk $M W$ and Wirth Faja B Oral health knowledge and attitudes of elementary schoolteachers in Michigan J Pbl Health Dent 1989, 49:44-50

27. Beiruti N, Tayfour D, Boles W and Poulsen S Oral-health-related knowledge and behaviour of a group of I5-year-old schoolchildren from Damascus, Syria In $t$ ] Paediatr Dent 1995, 5:187188
28. Sgan-Cohen HD, Saadi S and Weissman A Dental knowledge and attitudes among Arab schoolteachers in northern Israel Int Dent J 1999, 49:269-274

\section{Pre-publication history}

The pre-publication history for this paper can be accessed here:

http://www.biomedcentral.com/1472-6831/3/2/prepub
Publish with Bio Med Central and every scientist can read your work free of charge

"BioMed Central will be the most significant development for disseminating the results of biomedical research in our lifetime. "

Sir Paul Nurse, Cancer Research UK

Your research papers will be:

- available free of charge to the entire biomedical community

- peer reviewed and published immediately upon acceptance

- cited in PubMed and archived on PubMed Central

- yours - you keep the copyright
BioMedcentral 